\title{
Proteomic analysis of the effects of exogenous calcium on hypoxic-responsive proteins in cucumber roots
}

\author{
Lizhong He${ }^{1+}$, Xiaomin $\mathrm{Lu}^{1,2+}$, Jing Tian ${ }^{1}$, Yanjuan Yang ${ }^{1}$, Bin $\mathrm{Li}^{1}$, Jing $\mathrm{Li}^{1}$ and Shirong Guo ${ }^{{ }^{*}}$
}

\begin{abstract}
Background: Hypoxia acts as a plant stress factor, particularly in cucumbers plants under hydroponic culture. Calcium is involved in stress signal transmission and in the growth of plants. To determine the effect of exogenous calcium on hypoxic-responsive proteins in cucumber (Cucumis sativus L. CV. Jinchun No.2) roots, proteomic analysis was performed using two-dimensional electrophoresis (2-DE) and mass spectrometry.

Results: Cucumber roots were used to analyze the influence of hypoxia on plants. The expressions of 38 protein spots corresponding to enzymes were shown to change in response to hypoxia. Of these, 30 spots were identified by matrix-assisted laser desorption/ionization-time of flight mass spectrometry (MALDI-TOF/TOF MS analysis). The proteins were categorized according to functional groups, including glycolysis, the tricarboxylic acid (TCA) cycle, fermentative metabolism, nitrogen metabolism, energy metabolism, protein synthesis and defense against stress. Exogenous calcium appeared to alleviate hypoxic stress via these metabolic and physiological systems. Western blotting was used to analyze the accumulation of alcohol dehydrogenase (ADH) and pyruvate decarboxylase (PDC); calcium further increased the expression of $\mathrm{ADH}$ and PDC under hypoxia. In addition, semi-quantitative reverse transcription-polymerase chain reaction (RT-PCR) was used to assess the transcript levels of differentially expressed proteins.

Conclusions: Exogenous calcium enhanced the expression of enzymes involved in glycolysis, the TCA cycle, fermentative metabolism, nitrogen metabolism, and reactive oxygen species (ROS) defense in plants under hypoxia. Calcium appears to induce hypoxic tolerance of cucumber seedlings. These phenomena have prompted us to further investigate the mechanisms by which cucumbers respond to exogenous calcium under hypoxia.
\end{abstract}

Keywords: Cucumber, Calcium, Hypoxic stress, Proteomics

\section{Background}

Cultivated plants that produce vegetables, crops and fruits are frequently subjected to submerged conditions (so-called hypoxia) caused by flooding [1], waterlogging [2], irrigation or hydroponic culture [3]. Plants subjected to hypoxia undergo dramatic metabolic changes and induce defensive mechanisms to cope with the potential damage caused. Hypoxia induces enhanced aerenchyma formation, stem elongation, gas film around submergedleaves [4] and shoot biomass [5]. The first process to be

\footnotetext{
* Correspondence: srguo@njau.edu.cn

${ }^{\dagger}$ Equal contributors

'College of Horticulture, Nanjing Agriculture University/Key Laboratory of Southern Vegetable Crop Genetic Improvement, Ministry of Agriculture, Nanjing 210095, P. R. China

Full list of author information is available at the end of the article
}

influenced by the metabolic change induced by a shortage of oxygen is respiration. Hypoxic stress interferes with the electron transport system causing a lack of suitable electron acceptors, which appears to be linked to the saturated conditions of a redox state, accumulation of $\mathrm{NAD}(\mathrm{P}) \mathrm{H}$ and suppressed synthesis of ATP [6]. Energy from respiratory metabolism is necessary for the growth and yield of plants. Cucumber plants are sensitive to hypoxia, which frequently causes large reductions in yield [7].

Exogenous calcium can improve the suppression of growth/development of plants and help to maintain cell function by relieving gene repression caused during salt stress [8], anoxia [9], and chilling [10]. The involvement of calcium in oxygen debt responses is also observed in many plants. For example, the oxygen debt (anoxia) in cells of maize, rice and wheat plants causes a rise in

\section{Biomed Central}


cytoplasmic $\mathrm{Ca}^{2+}$ concentration $[11,12]$. In addition, elevated calcium levels significantly influence metabolic fluxes and substrate oxidation under hypoxic condition [13]. According to our previous research [14], exogenous calcium enhances the biomass and soluble protein content of cucumber seedlings under hypoxia (Additional file 1: Table S1). Thus, calcium appears to act as a signaling component during anoxia signal transduction in plants. The alteration in $\mathrm{Ca}^{2+}$ concentration seems to decrease cytosolic $\mathrm{pH}$, which probably represents a major signal in cells under suspension culture and in intact seedlings [15]. However, the mechanism of calcium's involvement in resistance to hypoxia remains unclear.

Proteomic analysis, commonly using mass spectrometry (MS), is a powerful technique that facilitates the visualization and comparison of complex mixtures of proteins. Proteomic analysis provides a large amount of information on individual proteins involved in specific biological responses. Recently, there have been many proteomic studies of cucumber plants [7,16-22]; however, none of them investigated the effects of exogenous calcium on the proteome of cucumber seedlings under root-room hypoxia stress. The purpose of the present study is to use proteomics to clarify the relationship between calcium and proteins in cucumber plants under hypoxic stress. We found that exogenous calcium could enhance both responsive metabolism and fermentative metabolism of cucumber seedlings, improving their tolerance to hypoxia. The results should provide a basis for future studies at both the physiological and molecular levels.

\section{Results and discussion}

\section{Identification and functional classification of proteins by} MALDI-TOF/TOF

To examine the effect of exogenous calcium on the proteome of cucumber seedlings under hypoxic stress in water culture, 2-DE analysis of total proteins in the roots was performed. Root proteins were extracted from $\mathrm{cu}-$ cumber seedlings exposed to normoxic, hypoxic and hypoxic $+4 \mathrm{mM} \mathrm{CaCl}_{2}$ (hypoxic $+\mathrm{Ca}^{2+}$ ) conditions. Proteins purified from roots were separated by 2-DE and analyzed by Imagemaster ${ }^{\mathrm{rm}} 2 \mathrm{D}$ Platinum software; the $\mathrm{p} I$ value and molecular masses of these protein spots ranged from 4 to 7 and from 14.4 to $116.0 \mathrm{kDa}$, respectively. The characteristics of proteins in representative gels are shown in Figure 1 and described below.

Approximately 500 spots were detected in Coomassie blue (CBB)-stained gels. Thirty-eight of these spots showed significant changes in relative volume $(>1.5$-fold) and were excised from the gels for MALDI-TOF/TOF MS analyses.

Thirty spots were identified using the NCBI viridiplantae database (V.2010.12.10, 184045 sequences) and the NCBI EST viridiplantae database (V.2010.12.10, 1847412 sequences), giving an identification success rate approximately 79\%. The results are summarized in Table 1 . Four proteins (spots 2,11, 12 and 36) expressed under normoxic and hypoxia $+\mathrm{CaCl}_{2}$ conditions did not appear to be expressed in hypoxia-treated plants. Spot 28 was present in plants under hypoxia and hypoxia $+\mathrm{CaCl}_{2}$, but was not present in plants under normoxic condition. Sixteen proteins (spots 4, 5, 8, 10, 13, 15, 16, 17, 18, 20, 22, $25,27,30,32$ and 37 ) were downregulated in hypoxiatreated plants, but upregulated in hypoxia $+\mathrm{Ca}^{2+}$ treated plants. Four proteins (spots 24, 33, 34 and 38) were downregulated under hypoxia and hypoxia $+\mathrm{CaCl}_{2}$ condition. The expressions of two proteins (spots 14 and 19) under hypoxia $+\mathrm{CaCl}_{2}$ conditions were significantly greater than those under normoxic and hypoxic conditions. Two proteins (spot 26 and 31) were upregulated under hypoxic conditions and further upregulated under hypoxia $+\mathrm{CaCl}_{2}$ conditions. Spot 1 was significantly accumulated under hypoxic and normoxic conditions.

Eight identified spots (spots 1, 2, 13, 14, 15, 24, 37 and 38) were annotated either as unnamed proteins or ESTs in the databases, and three spots (spots 25, 32, 34) were described in The Rice Annotation project Database (RAP-DB). We searched for their homologs using BLAST http://www.ncbi. nih.gov/BLAST/ and their protein or nucleotide sequences as queries. The six proteins showing the highest similarity are listed in Table 2. These similar proteins showed more than $85 \%$ positives at the amino acid level, indicating that they might have similar functions. The remaining 19 identified proteins were involved in various biological processes and could be classified into three groups [23,24]. The first group consists of proteins involved carbon metabolism, nitrogen metabolism, and energy metabolism. The second group consists of regulatory proteins involved in translation and synthesis. The third group consists of proteins participating the stress response.

\section{Structural proteins and enzymatic proteins involved in energy metabolism}

Most of the identified proteins were structural proteins (non-enzymatic proteins) and enzymes involved in energy metabolism. These enzymes seem to have particularly important roles in cucumber plants under hypoxic conditions. The expressions of cytoplasmic aconitate hydratase (spot 4), pyruvate dehydrogenase 2 (spot 20), cytoplasmic malate dehydrogenase (spot 22) and pyruvate dehydrogenase e1 alpha subunit (spot 27) from the TCA cycle were downregulated under hypoxic conditions, but upregulated under hypoxia $+\mathrm{CaCl}_{2}$ conditions The TCA cycle is a key component of the metabolic pathway by which all aerobic organisms generate energy by oxidization of pyruvate into carbon dioxide and water. Pyruvate dehydrogenase 2 (PDH2), a pyruvate dehydrogenase E1 beta isoform, and pyruvate dehydrogenase 


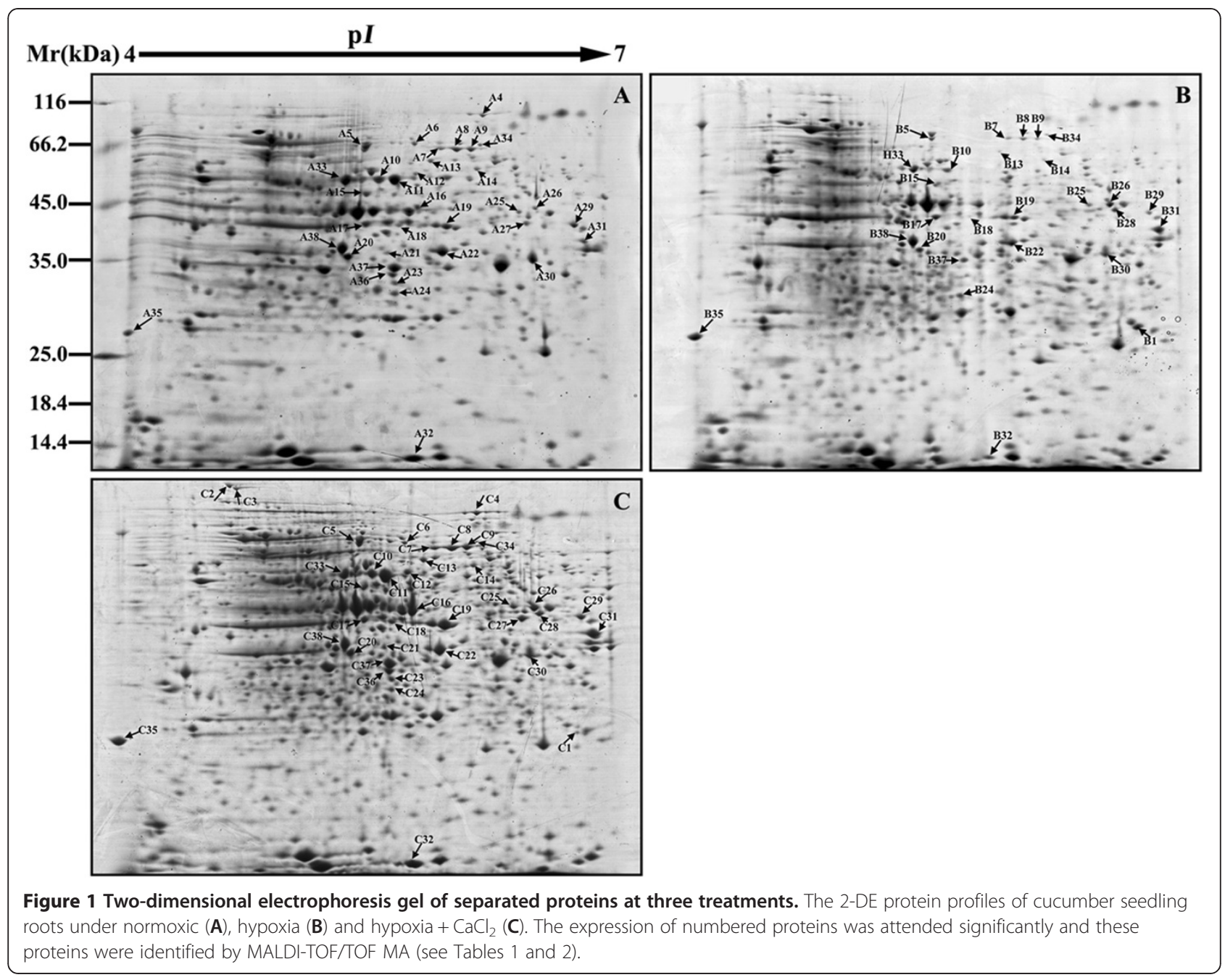

e1 alpha subunit are involved in the formation of cellular energy through the TCA cycle and in the synthesis of acetylcholine (acety1-CoA). Acetyl-CoA may then be used in the TCA cycle to carry out cellular respiration; thus, pyruvate dehydrogenase links the glycolytic pathway to the TCA cycle and releases energy via NADH. Calcium activates pyruvate dehydrogenase, isocitrate dehydrogenase (IDH) and $\alpha$-ketoglutarate dehydrogenase [25]. Aconitate hydratase (aconitase) catalyses the stereospecific isomerization of citrate to isocitrate via cis-aconitate in the TCA cycle $[26,27]$. Malate dehydrogenases $(\mathrm{MDH})$, which is essential to the TCA cycle, catalyses the conversion of oxaloacetate to malate [28]. Increased malate levels in plants contributes to plant acid resistance and aluminum toxicity tolerance [29]. In apples and tomatoes, significant accumulation of malate dehydrogenases gene transcripts is related to plant and cell growth, as well as to tolerance of salt stress [30]. The activities of enzymes such as succinate dehydrogenase (SDH), isocitrate dehydrogenase (IDH) and malate dehydrogenase (MDH) in the TCA cycle are different between the hypoxia and hypoxia + $\mathrm{CaCl}_{2}$ conditions, where exogenous calcium promotes the actives of SDH and IDH in cucumber [31]. Moreover, calcium acts to maintain higher activities of $\mathrm{MDH}$ and $\mathrm{SDH}$ and a certain level of aerobic respiration in pepper [32]. Thus, exogenous calcium seems to induce tolerance to hypoxia in cucumber plants through the activation of the enzymes involved in the TCA cycle.

Cytosolic enolase is expressed in many plant species in response to various environmental stresses, such as salt stress [33], cold [34,35] and drought [36]. However, the level of protein expression appears not to be correlated with the enzyme's activity. Although enolase activity was increased by the stresses, the level of expression of the enolase protein showed no fluctuation [37] or was even observed to significantly decrease [33]. In the present study, this enolase (spots 10 and 11) appeared to be downregulated under hypoxia compared to hypoxia + $\mathrm{CaCl}_{2}$ and control. These results imply that enolase activity is regulated at the posttranscriptional level under 
Table 1 Differentially expression proteins identified by MALDI-TOF/TOF MS

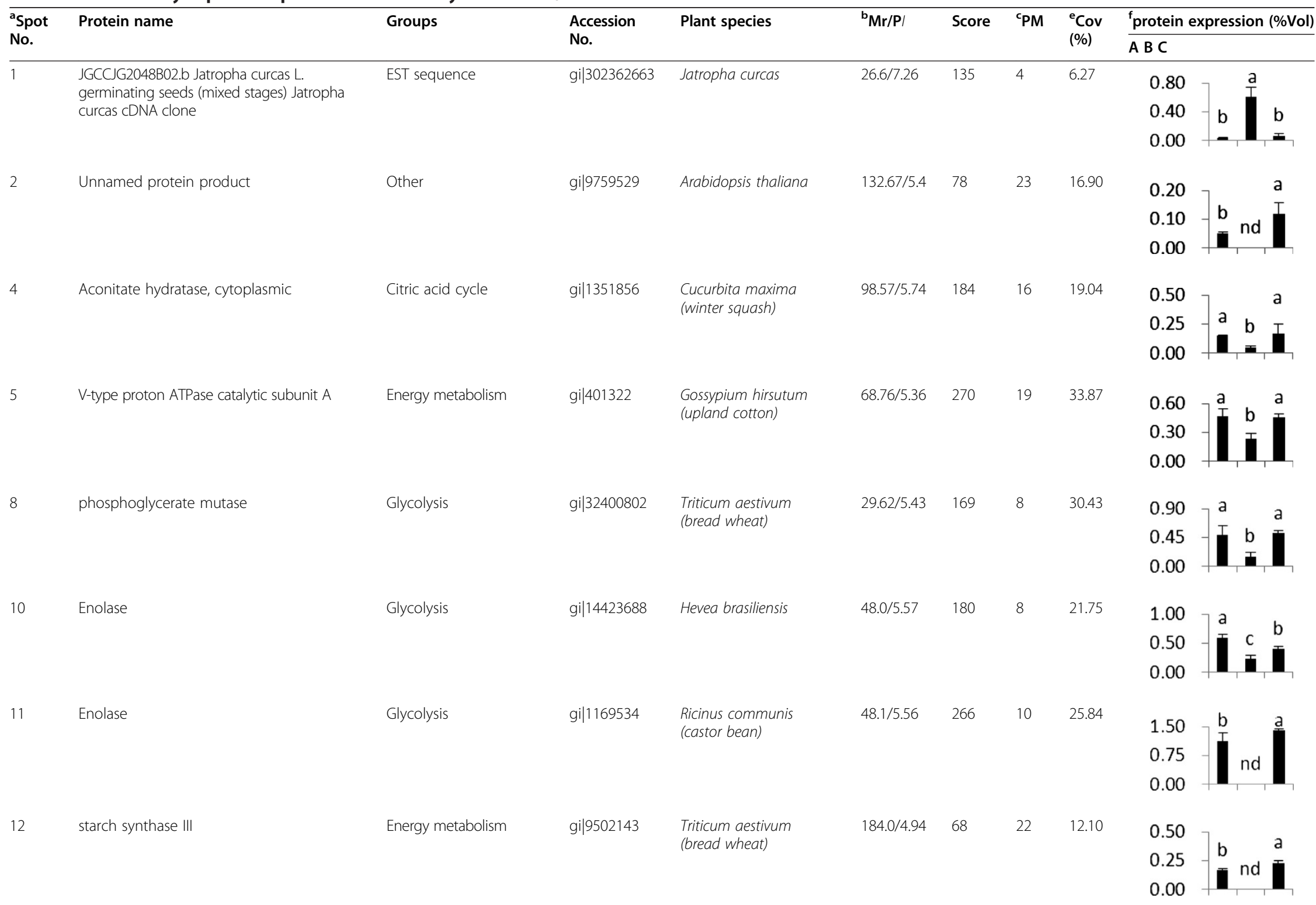




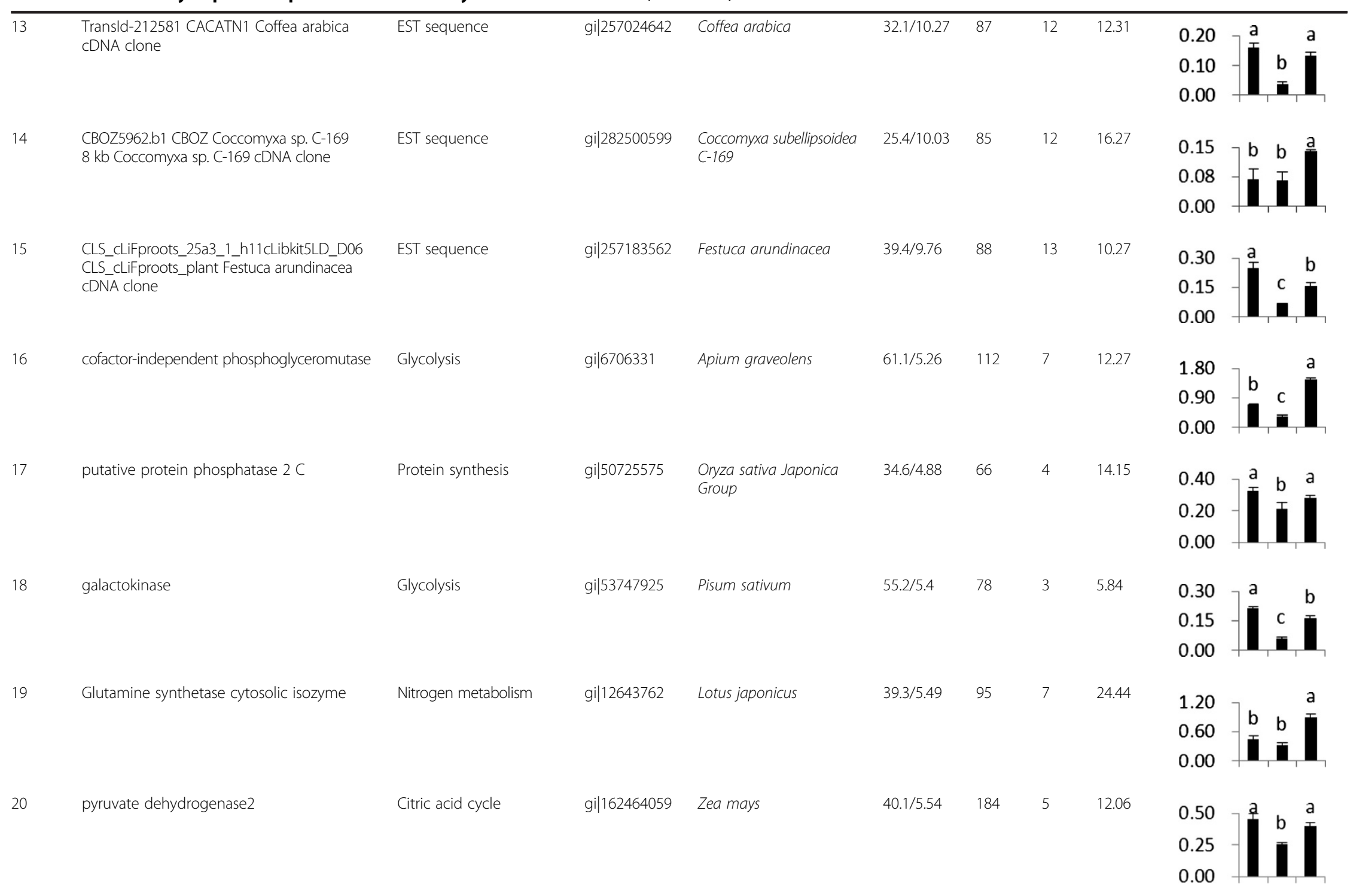


$35.9 / 6.39$

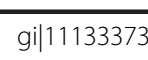

CLS_CLiFproots_52a4_1_b18cLibkit5LD_ A09 CLS_CLiFproots_plant Festuca arundinacea cDNA clone

$25 \quad$ Os03g0851100

26

alcohol dehydrogenase

putative pyruvate dehydrogenase e1 alpha subunit

Glycolysis

gi|15227981

Arabidopsis thaliana

Defense against stress

\section{EST sequence}

gi|257180604

Festuca arundinaced

Other

Fermentative metabolism

Protein synthesis

gi|4091008

Oryza sativa (rice)
$31 \quad$ peroxidase

gi|167531 $\begin{aligned} & \text { Cucumis sativus } \\ & \text { (cucumber) }\end{aligned}$

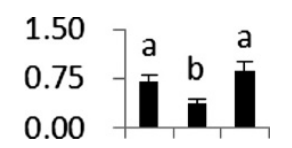

$\begin{array}{llll}41.9 / 10.49 & 100 & 14 & 11.14\end{array}$

$\left.\begin{array}{l}0.28 \\ 0.14 \\ 0.00\end{array}\right] \stackrel{a}{a}$

$\left.\begin{array}{l}0.18 \\ 0.09 \\ 0.00\end{array}\right] \begin{array}{lll}a & b & \frac{a}{a}\end{array}$

$\begin{array}{llll}33.1 / 6.08 & 173 & 7 & 24.44\end{array}$

$\left.\left.\begin{array}{l}0.50 \\ 0.25 \\ 0.00\end{array}\right]\right]_{\mathrm{c}}^{\mathrm{c}} \mathrm{b}_{1}^{\mathrm{b}}$

$\left.\begin{array}{l}0.40 \\ 0.20 \\ 0.00\end{array}\right]^{\mathrm{I}} \begin{array}{lll}\mathrm{b} & \mathrm{a} \\ \mathbf{a}_{1}\end{array}$

$\begin{array}{llll}90.9 / 6.55 & 78 & 15 & 18.66\end{array}$

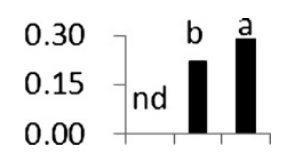

$\begin{array}{llll}38.7 / 7.01 & 282 & 8 & 27.37\end{array}$

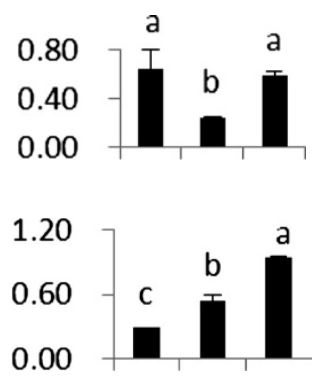


Table 1 Differentially expression proteins identified by MALDI-TOF/TOF MS (Continued)

32 Os02g0121900 Other

Oryza sativa Japonica

$70.3 / 9.39$

73

14

28.69

$\left.\left.\begin{array}{l}1.20 \\ 0.60 \\ 0.00\end{array}\right]=\begin{array}{lll}a & b \\ 0.14 \\ 0.07\end{array}\right]$

${ }^{a}$ Spot numbers are given in Figure 1

${ }^{\mathrm{b}}$ Theoretical molecular mass (Mr) and isoelectric point (pl) of the identified proteins. ${ }^{\mathrm{e}}$ The percent coverage of peptides.

fhe relative levels of protein expression. A: normoxic; B: hypoxia; C hypoxia $+\mathrm{CaCl}_{2}$. 
Table 2 Homologs of unknown proteins

\begin{tabular}{|c|c|c|c|c|c|c|}
\hline \multirow{2}{*}{$\begin{array}{l}\text { Spot } \\
\text { No. }\end{array}$} & \multirow{2}{*}{$\begin{array}{l}\text { Accession } \\
\text { No. }^{a}\end{array}$} & \multicolumn{5}{|l|}{ Homologue } \\
\hline & & NCBI accession No. ${ }^{b}$ & Protein Name & Plant species & Ident $^{\mathrm{c}}$ & $\operatorname{Pos}^{d}$ \\
\hline $\mathrm{B} 1$ & gi|302362663 & CAl83772.1 & glyceraldehyde-3-phosphate-dehydrogenase & Lupinus albus & $93 \%$ & $97 \%$ \\
\hline 2 & gi|9759529 & NP_200612.2 & FIP1 [V]-like protein & Arabidopsis thaliana & $99 \%$ & $99 \%$ \\
\hline 13 & gi|257024642 & ACD03224.1 & xyloglucan endotransglucosylase & Actinidia deliciosa & $77 \%$ & $91 \%$ \\
\hline 25 & gi|115456623 & AAG32661.1 & translational elongation factor EF-TuM & Zea mays & $89 \%$ & $94 \%$ \\
\hline 32 & gi|115443885 & XP_003573599.1 & $\begin{array}{l}\text { pentatricopeptide repeat-containing protein } \\
\text { At1g02060 }\end{array}$ & Brachypodium distachyon & $80 \%$ & $90 \%$ \\
\hline 34 & gi|115468776 & BAD33043.1 & putative protein phosphatase $2 \mathrm{C}$ & Oryza sativa Japonica Group & $100 \%$ & $100 \%$ \\
\hline
\end{tabular}

${ }^{\mathrm{a}}$ The gi number of the unknown proteins. ${ }^{\mathrm{b}}$ The accession number of homologues. ${ }^{\mathrm{C}}$ Identities. ${ }^{\mathrm{d}}$ Positives.

anaerobic conditions and its relative amount is increased by exogenous calcium during hypoxia.

The expression of phosphoglycerate mutase (PGAM) (spot 8) and cofactor-independent phosphoglyceromutase (iPGAM) (spot 16) markedly decreased under hypoxic stress, but increased on the addition of exogenous calcium. PGAM is a key enzyme in glycolysis, catalyzing the interconversion of the phosphate group from $\mathrm{C}-3$ to $\mathrm{C}-2$, which results in the conversion of 3-phosphoglycerate (3PGA) to 2-phosphoglycerate (2PGA). PGAMs are divided into two evolutionarily unrelated groups based on whether they require 2, 3-biphosphoglycerate as a cofactor: cofactor dependent PGAMs (dPGAMs) and cofactor-independent PGAM (iPGAMs). The iPGAMs are commonly present in higher plants, some invertebrates, fungi, and bacteria [38]. PGAMs are important to stomatal movement, vegetative biomass production, and reproduction in Arabidopsis [39]. Transgenic potato plants with reduced iPGAM enzyme activity showed reduced growth because of a reduced photosynthetic rate [40]. These phenomena suggest that the conversion of 3PGA to 2PGA may be inhibited under hypoxia, and that exogenous calcium may increase the abundance of the proteins.

Fructose-bisphosphate aldolase (FBP aldolase, spot 30) is also an essential enzyme involved in glycolysis. It catalyzes a reversible cleavage reaction of fructose-1, 6-bisphosphate (F-1, 6-BP) into two trioses: glyceraldehydes-3-phosphate and dihydroxyacetone phosphate (DHAP) [41]. Increased FBP aldolase activity stimulates the glycolytic pathway and plays an important role in gibberellin A (GA)-induced growth of rice roots [42] and in signal transduction [43]. In the present study, downregulation of FBP aldolase under the hypoxia altered the levels of glycolysis and inhibited the growth of cucumber roots. Exogenous calcium significantly elevated the quantity of the FBP aldolase, which may help alleviate the effects of hypoxic stress. This result is consistent with the expression profile of this protein in cucumber roots under salt stress [20].
The glycolytic pathway is the major source of energy when oxygen availability decreases below the level at which oxygen becomes limiting for oxidative phosphorylation [44]. Pyruvate produce from glycolysis is consumed by fermentative metabolism, which involves pyruvate decarboxylase (PDC) and alcohol dehydrogenase (ADH, spot 26). $\mathrm{ADH}$ catalyzes the reduction of pyruvate to ethanol and results in continuous $\mathrm{NAD}^{+}$regeneration. $\mathrm{ADH}$ is considered essential for survival of plants during anaerobic conditions [45]. Ruthenium red, an organelle calcium channel blocker, dramatically reduced anoxia-induced ADH activity [46] and gene expression [47]. As expected, the quantity of $\mathrm{ADH}$ was increased under hypoxia and increased further under hypoxia $+\mathrm{CaCl}_{2}$.

Spot 12, spot 18 and spot 36 were identified as starch synthase III (SSIII), galactokinase and fructokinase, respectively. SS is involved in the elongation of the linear chains of starch [48]. SSIII specifically catalyzes the formation of chains with a degree of polymerization (DP) of 12 to 25. Other SS isoforms cannot fulfill this function [49]. Galactokinase is involved in the conversion of stachyose to sucrose in the cucumber peduncle [50]. Fructokinase specifically catalyzes the transfer of a phosphate group from ATP (the substrate) to fructose as the initial step in its utilization. Recent studies have suggested that sucrose and hexoses (mainly glucose and fructose) can act as sensing-molecules to elicit sugar responses in both source and sink organs when plants are under abiotic stress [51], and can control distinct aspects of plants' development [52]. In the present study, these enzymes were significantly downregulated under hypoxia, but upregulated under hypoxia $+\mathrm{CaCl}_{2}$. A decrease of starch or carbon metabolic activity was also observed in other studies using various plant species under hypoxia $[44,53]$. These observations provide a convenient explanation of the adaptive response of plants to hypoxia, namely that plants limit their energy consumption by suppressing the synthesis of storage 
substances, such as starch and protein $[54,55]$. Calcium seems to enhance carbohydrate metabolism and induces sugar signaling to enhance tolerance of cucumber plants subjected to hypoxic stress.

According to recent studies using transgenic plants, overexpression or altered expression of glutamine synthetase (GS) promotes the development of plants [56] such as wheat [57] and Lotus corniculatus [58]. The expression of this protein (GS, spot 19) decreased under hypoxia, but was significantly enhanced under hypoxia $+\mathrm{CaCl}_{2}$. Thus, calcium appears to regulate nitrogen $(\mathrm{N})$ metabolism through GS to relieve $\mathrm{O}_{2}$-deficient conditions in cucumber plants subjected to hypoxia.

ATP synthases (ATPases) are membrane-bound enzyme complexes/ion transporters that combine ATP synthesis and/or hydrolysis with the transport of protons through the membrane [20], playing a key role in biological energy metabolism. ATPases differ in respect to function (ATP synthesis and/or hydrolysis), structure (F-, V- and AATPases contain rotary motors) and in the type of ions they transport $[59,60]$. Two ATPases, i.e. V-type proton ATPase catalytic subunit A (spot 5) and F1-ATP synthase, beta subunit (spot 33) were remarkably decreased under hypoxia. Under hypoxia $+\mathrm{CaCl}_{2}$, the level of the former (spot 5) was restored and the latter (spot 33) showed a tendency to be somewhat restored. These restored levels did not reach the level of the control (normoxic conditions). V-type proton ATPases generate a proton electrochemical gradient, which is the driving force utilized by the tonoplast $\mathrm{Na}^{+} / \mathrm{H}^{+}$antiporter, to compartmentalize $\mathrm{Na}^{+}$into the vacuole [61]. F1-ATPases in mitochondria, chloroplasts and bacterial plasma membranes are the prime producers of ATP, using the proton gradient generated by oxidative phosphorylation (mitochondria) or photosynthesis (chloroplasts). Mitochondrial $\mathrm{Ca}^{2+}$ accumulation triggers activation of mitochondrial metabolism, which increases ATP synthesis in mitochondria and ATP levels in cytosol [62]. This phenomenon suggests that hypoxia dramatically inhibits energy metabolism in cucumber plants, and in the case of these two ATPases, calcium cannot completely restore them to normoxic levels.

Calcium is an essential element for cell growth and plays a role as a second messenger in signal transduction pathways [63]. Therefore, it is not surprising that calcium is implicated in plant metabolism regulation signaling, particularly in association with oxygen deprivation [64]. According to Gao et al., exogenous calcium induces the promotion of physiologically active factors and matters in muskmelon plants, as compared to the factors and matters observed in plants under hypoxic stress after 6 days [65]. $\mathrm{CaCl}_{2}$ pretreatment increased the accumulation of amino acids in rice roots under anaerobic stress, possibly via a $\mathrm{Ca}-\mathrm{Camodulin}$ complex involved in the transduction of an anaerobic signal that inhibits proteolysis and solute release
[9]. In addition, downregulation of a suite of energy metabolic pathways, and therefore, oxygen-consumption, is a class of plant hypoxic responses [66]. In the present study, enzymes of carbon and nitrogen metabolism in the cytosol, mitochondria and chloroplasts were significantly induced by exogenous calcium. Thus, calcium enhances the tolerance of cucumber plants under hypoxia by regulating metabolic systems in the glycolytic pathway and the TCA cycle, and the activity of enzymes, such as ADH and GS. Although exogenous calcium had only a slight effect on ATPases, this effect seems to be part of the global effect of calcium on metabolism in cucumber plants.

\section{Regulatory proteins}

Plant growth and productivity is suppressed by hypoxic stress or flooding [67]. As the cell metabolism adapts to hypoxia, increased protein degradation might control the levels of one or more regulators/enzymes [68]. Protein phosphatase 2C (PP2Cs, spot 17) decreased under hypoxia and increased under hypoxia $+\mathrm{CaCl}_{2}$. This enzyme is a negative regulator of stress signaling in plants and mammals [69] and acts predominantly through the signaling pathway of the stress hormone, abscisic acid (ABA) [70]. Thus, the increase in the amount of the enzyme under hypoxia $+\mathrm{CaCl}_{2}$ may imply that the exogenous calcium influences ABA signaling to relieve hypoxic stress. Spot 28 was identified as methionyl-tRNA synthetase (MetRS). This enzyme is a multi-domain protein that specifically binds tRNA ${ }^{\text {Met }}$ and catalyzes the synthesis of methionyltRNA $^{\text {Met }}$ [71], giving it a vital role in protein biosynthesis. The MetRS gene has been described in the mitochondria and chloroplasts of Arabidopsis thaliana [72] and has been linked with plant cell anti-oxidant defense during oxidative stress [73]. Although MetRS was not detected under normoxic conditions, it was induced under hypoxia and further increased under hypoxia $+\mathrm{CaCl}_{2}$. This result suggests that the expression of MerRS under hypoxia represents a stress response of the cucumber seeding and calcium enhanced this response under hypoxic stress.

\section{Proteins related to the stress response}

Excessive generation of reactive oxygen species (ROS) or oxidative stress is an integral part of many stress situations, including hypoxia [74]. Higher plants have active oxygen-scavenging systems, consisting of multiple defense enzymes that can modulate the steady-state level of ROS [75]. Peroxidase (POD, spot 31), a ubiquitous enzyme [76] present in plants, microbes, fungi and vertebrates. This enzyme acts as a biological catalyst to scavenge $\mathrm{H}_{2} \mathrm{O}_{2}$ [77]. The activities and gene expressions of superoxide dismutase (SOD) and ascorbate peroxidase (APX) were increased in pigeon pea [78], mung bean [74] and cucumber $[79,80]$ under waterlogged conditions. These phenomena were consistent with the 
changes in the expression of POD in the present study. In addition, the expression of POD was further increased by treatment with calcium. Thus, exogenous calcium can enhance the activities of ROS-scavenging enzymes to defend against the damage caused by ROS, which would suppress the effects of hypoxic stress.

\section{Validation of differentially expressed proteins by western blotting}

To maintain ATP levels in plants under hypoxia, the plants seem to continuously regenerate of $\mathrm{NAD}^{+}$in the cytosol (glycolysis) and mitochondria (TCA cycle). Ethanol formed by alcohol fermentation diffuses rapidly out of the cells, inducing a considerable loss of carbon during hypoxia. In this regard, pyruvate decarboxylase (PDC) and alcohol dehydrogenase (ADH) are considered as important plant proteins for coping with hypoxiainduced cellular damage [81]. According to Kang et al. [82], 24-epibrassinolide (EBR) further enhances ADH activity in hypoxic cucumber roots. Therefore, PDC and $\mathrm{ADH}$ were analyzed by western blotting to verify the proteomic data. As shown in Figure 2, the expression of $\mathrm{PDC}$ and $\mathrm{ADH}$ seems to change among plants grown under the three culture conditions. The PDC protein levels were upregulated under hypoxia, as compared to normoxic (control) conditions, and was further upregulated under hypoxia $+\mathrm{CaCl}_{2}$. Under hypoxia and hypoxia $+\mathrm{CaCl}_{2}, \mathrm{ADH}$ showed a similar tendency that of PDC, although the level of ADH under normoxic conditions was very low. The western blot results correspond well with the proteomic results and were consistent with previous research.

\section{Transcript accumulation patterns for 12 candidate proteins} RT-PCR was used to analyze the changes in gene expression at the mRNA level of 12 identified proteins involved in glycolysis, the TCA cycle, energy metabolism, nitrogen metabolism, fermentative metabolism and defense against stress (Figure 3,A and B). Different peptide sequences obtained from protein spots were used to

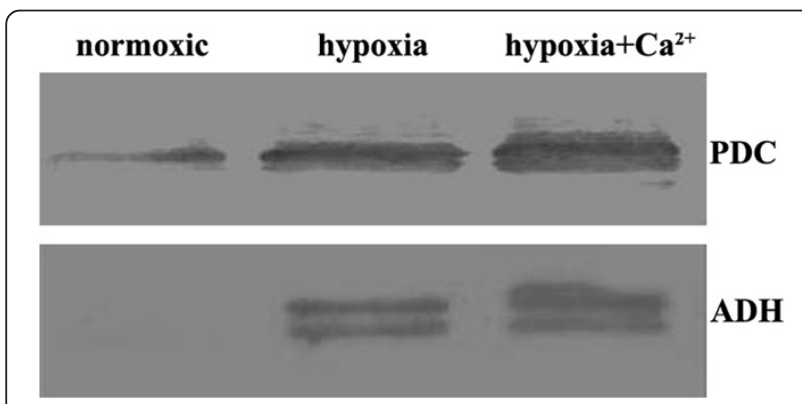

Figure 2 Western blot analysis of PDC and ADH expression level under three treatments. design primers to compare mRNA accumulation under control, hypoxia and hypoxia $+\mathrm{CaCl}_{2}$ conditions, 3 days after treatment. As shown in Figure $3 \mathrm{~A}$ and $\mathrm{B}$, the mRNA levels of seven transcripts (vatps, ela, adh, gas, $p d h, m d h$, atp $\beta$, and ald) increased under hypoxia and decreased under hypoxia $+\mathrm{CaCl}_{2} ;$ adh expression was not detected under normoxic conditions. The gene expressions of $s s$ and pod increased under hypoxic stress and further increased under hypoxia $+\mathrm{CaCl}_{2}$. The ach gene showed an opposite tendency. Thus, the mRNA levels did not correspond with the protein levels. This is not surprising, because the final amount and activity of a protein represents an accumulation regulatory events at their transcriptional, post-transcriptional, translational, and post-translational levels [83]. Therefore, the validity of estimating gene expression levels using protein expression data requires further study.

\section{Conclusions}

Proteomic analysis is an effective means for clarifying protein expression patterns and permits the identification of candidate proteins. In the present study, calcium was demonstrated to be involved in the short-term hypoxic tolerance of cucumber plants. Exogenous calcium enhanced the expression of proteins involved in glycolysis, the TCA cycle, nitrogen metabolism, protein synthesis, fermentative metabolism and ROS defense. This phenomenon suggests that exogenous calcium could induce hypoxia tolerance by improving enzyme activity in systems related to respiratory metabolism and stress defense in cucumber plants. However, western blotting and RT-PCR analyses showed different results for the candidate proteins. In general, exogenous calcium improves the hypoxia tolerance of plants via multiple systems that are regulated by multiple genes relating to various metabolic and signaling pathways. The present study provides evidence of the mitigating effect of exogenous calcium on the growth and metabolic activities of cucumber plants restrained under hypoxia. Further proteomic studies in this area are clearly warranted and are ongoing.

\section{Methods}

\section{Plant materials and growth conditions}

Cucumber (Cucumis sativus L. cv. Jinchun No.2, hypoxia sensitive [84]) seeds were sterilized with $0.5 \%$ (W/V) sodium hypochlorite solution for $10 \mathrm{~min}$ and then washed thoroughly with deionized water. The washed seeds were sown on two layers of wet filter paper and incubated in the dark at $28^{\circ} \mathrm{C}$ for $24 \mathrm{~h}$. The germinated seedlings were transplanted to plastic trays $(41 \times 41 \times 5 \mathrm{~cm})$ containing quartz sand and grown at $25-30^{\circ} \mathrm{C}$ (day) and $15-18^{\circ} \mathrm{C}$ (night), with $60-75 \%$ relative humidity (RH), in a greenhouse of Nanjing Agriculture University in 2010. The seedlings were supplied with 1/2-strength Hoagland's nutrient solution ( $\mathrm{pH} 6.5 \pm 0.1$, EC $2.0-2.2 \mathrm{dS} \mathrm{m}^{-1}$ ). At the 

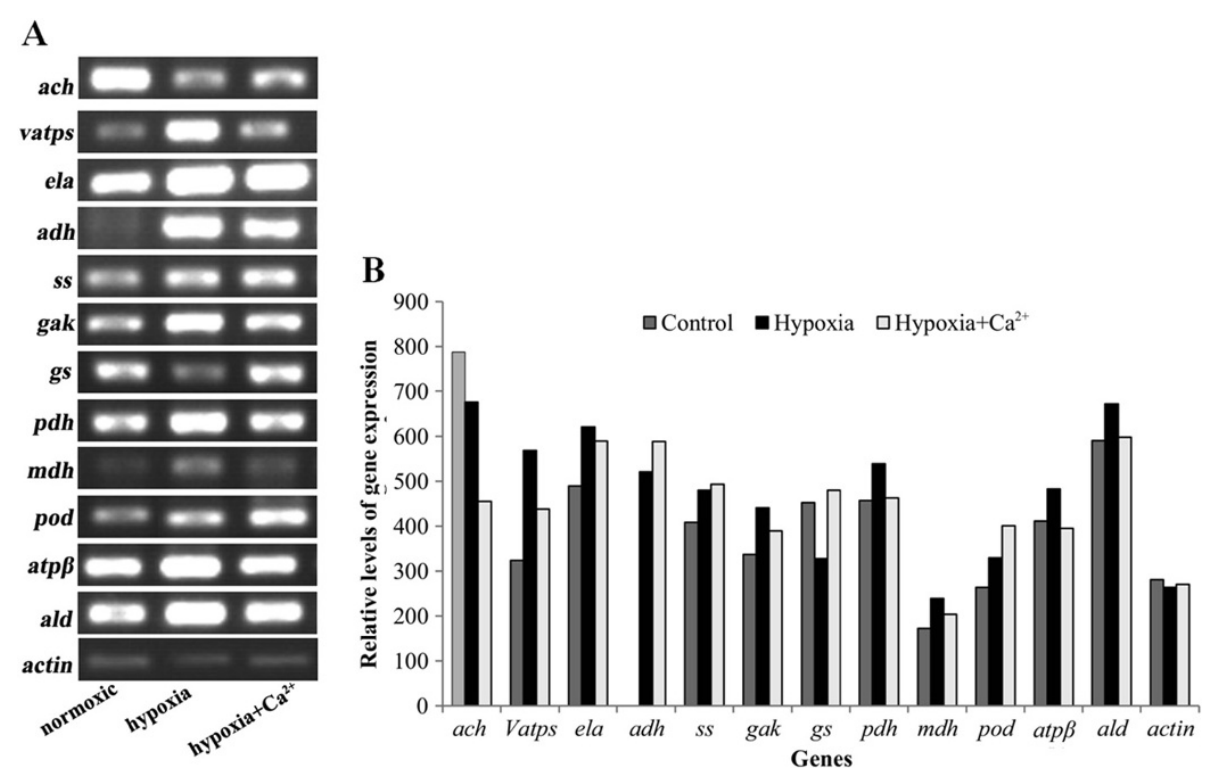

Figure 3 RT-PCR analysis of transcript levels of differentially expressed proteins under three treatments. ach: aconitate hydratase; vatps: V-type proton ATPase; ela: enolase; adh: alcohol dehydrogenase; ss: starch synthase; gak: galactokinase; gs: glutamine synthetase; pdh: pyruvate dehydrogenase; mdh: malate dehydrogenase; pod: peroxidase; atp $\beta$ : F1-ATP synthase, beta subunit; ald: aldolase. Transcript levels were measured three days after the treatments $(\mathbf{A})$, and the relative abundance ratio of the genes was analyzed (B). A single concentration of cDNA was also used for amplification with ACTIN (AF171095, actin) primers. ACTIN was used as the internal standard to determine the extent of cDNA amplification.

2nd leaf development stage, relatively uniform seedlings were transferred to tanks containing full strength Hoagland's nutrient solution. The solution was renewed every 3 days. The solution in the tanks was kept at $20-25^{\circ} \mathrm{C}$ and aerated with an air pump to keep the dissolved oxygen (DO) level at $8.0 \pm 0.2 \mathrm{mg} \mathrm{L}^{-1}$ (the optimum DO level for cucumber). At the 3rd leaf development stage, seedlings were subjected to one of three treatments. (1) Control: $1 / 2$ Hoagland's solution (containing $2 \mathrm{mM} \mathrm{Ca}^{2+}$ ) with $\mathrm{DO}$ of $8.0 \pm 0.2 \mathrm{mg} \mathrm{L}^{-1}$. (2) Hypoxia treatment: 1/2 Hoagland's solution (containing $2 \mathrm{mM} \mathrm{Ca}{ }^{2+}$ ) with DO of $1.0 \pm$ $0.1 \mathrm{mg} \mathrm{L}^{-1}$, which was prepared by pumping N2-gas into the nutrient solutions as the hypoxic treatment. The oxygen concentration in the nutrient solutions was monitored with an automatic DO control system (Quantum25, Quantum Analytical Instruments Inc., USA). (3) Hypoxia $+\mathrm{CaCl}_{2}$ treatment: $1 / 2$ Hoagland's solution + $4 \mathrm{mM} \mathrm{CaCl}_{2}$ with $\mathrm{DO}$ of $1.0 \pm 0.1 \mathrm{mg} \mathrm{L}{ }^{-1}$. The oxygen concentration in the nutrient solutions was controlled as in the hypoxia treatment.

\section{Protein extraction}

For analysis of total protein, root samples were harvested 3 days after the end of hypoxic treatment. Protein extraction was performed according to a modified version of the method of Hurkman [85]. Root samples (1-2 g fresh weight) were ground in a mortar with liquid nitrogen. The ground samples were suspended in $30 \mathrm{mM}$ 2-amino-2- (hydroxymethyl)-1,3-propanediole (Tris)- $\mathrm{HCl} \quad(\mathrm{pH} \quad 8.7)$ containing $1 \mathrm{mM}$ ethylene glycol-bis(2-aminoethylether)$\mathrm{N}, \mathrm{N}, \mathrm{N}^{\prime} \mathrm{N}^{\prime}$-tetraacetic acid (EGTA), $1 \mathrm{mM}$ dithiothreitol (DTT) and $1 \mathrm{mM}$ phenylmethyl sulfonyl fluoride (PMSF), and then centrifuged at $15,000 \mathrm{~g}$ for $20 \mathrm{~min}$. An aliquot $(1 \mathrm{ml})$ of the resulting supernatant was placed into a tube and precipitated with acetone containing 10\% TCA and $0.07 \% \quad \beta$-mercaptoethanol. The resulting protein sample was allowed to precipitate overnight at $-20^{\circ} \mathrm{C}$ and then centrifuged at 20,000 $\mathrm{g}$ for $25 \mathrm{~min}$. The pellet was rinsed three times with cold acetone containing $0.07 \% \beta$-mercaptoethanol and allowed to stand at $-20^{\circ} \mathrm{C}$ for $1 \mathrm{~h}$. Finally, the protein pellet was air-dried and used for 2-DE.

\section{2-DE}

Isoelectric focusing (IEF) was performed according to the methods of Duncan and Hershey [86] and O'Farrell [87]. The dried protein pellet was rehydrated in rehydration buffer: $7 \mathrm{M}$ urea, $2 \mathrm{M}$ thiourea, 4\% 3-[(3-cholanidopropyl) dimethylammonio]-1-propanesulfonic acid (CHAPS) (w/v), $40 \mathrm{mM}$ DTT, $0.5 \%$ (v/v) immobilized $\mathrm{pH}$ gradient (IPG) buffer $4-7$ and $0.01 \%(\mathrm{w} / \mathrm{v})$ bromophenol blue. Protein levels were quantified according to the Bradford method [88]. IPG strips of nonlinear pI 4-7 $(13 \mathrm{~cm})$ were loaded with $250 \mu \mathrm{l}$ of protein sample containing $800 \mu \mathrm{g}$ protein in a rehydration tray for 12-16 h at room temperature. Following rehydration, the IPG strips were run on an Ettan 
IPGphor 3 (GE Healthcare, USA). The voltage for IEF was set at $200 \mathrm{~V}$ for $1 \mathrm{~h}$, followed by $500 \mathrm{~V}$ for $1 \mathrm{~h}, 1000 \mathrm{~V}$ for $1 \mathrm{~h}, 3000 \mathrm{~V}$ for $30 \mathrm{~min}, 5000 \mathrm{~V}$ for $30 \mathrm{~min}$, gradient $8000 \mathrm{~V}$ for $30 \mathrm{~min}$, and $8000 \mathrm{~V}$ rapid focus, reaching a total of $35,000 \mathrm{Vh}$. The cell temperature was maintained at $20^{\circ} \mathrm{C}$ with a maximum current of $50 \mu \mathrm{A}$ per strip. After running the first dimension, IEF strips were equilibrated for 15 min with $10 \mathrm{ml}$ DTT buffer containing $6 \mathrm{M}$ urea, 30\% (v/v) glycerol, 2\% SDS, 1\% (w/v) DTT and $50 \mathrm{mM}$ Tris$\mathrm{HCl}$ (pH8.8) and then with iodoacetamide buffer with $2.5 \%(\mathrm{w} / \mathrm{v})$ iodoacetamide instead of DTT for $15 \mathrm{~min}$.

The second dimensional SDS-polyacrylamide gel electrophoresis (SDS-PAGE) was carried out on running gels (Hoefer SE600 Ruby Standard Vertical System, GE Healthcare; $12.5 \%$ polyacrylamide) in the presence of SDS, as described by Laemmli [89]. The strips were embedded on the top of the SDS-gel and then sealed using a 1\% molten agarose solution. Electrophoresis was carried out at $15 \mathrm{~mA}$ per gel until the bromophenol blue dye front reached about $1 \mathrm{~cm}$ from the bottom of the gel.

\section{Image acquisition and analysis}

For Coomassie brilliant blue (CBB) R-250 staining, the gels were fixed overnight in a mixture of $\mathrm{MeOH}-\mathrm{H}_{2} \mathrm{O}$ $(1: 1, v / v)$ and $\mathrm{AcOH}: \mathrm{H}_{2} \mathrm{O}(1: 9, \mathrm{v} / \mathrm{v})$ and then stained for $2 \mathrm{~h}$ in a mixture of $\mathrm{AcOH}: \mathrm{H}_{2} \mathrm{O}(1: 9, \mathrm{v} / \mathrm{v})$ and $0.1 \%(\mathrm{w} / \mathrm{v})$ CBB R-250. The stained gels were destained in a mixture of $\mathrm{MeOH}-\mathrm{H}_{2} \mathrm{O}(1: 1, \mathrm{v} / \mathrm{v})$ and $\mathrm{AcOH}: \mathrm{H}_{2} \mathrm{O}(1: 9, \mathrm{v} / \mathrm{v})$. The CBB-stained 2-D gels were scanned using an Image scanner III (GE Healthcare). The digitized images were analyzed with Imagemaster ${ }^{\text {TM }}$ 2D Platinum version 5.0 (GE Healthcare). At least three gels from each treatment in three independent experiments were used for the analysis. The intensities of spots were quantified based on their relative volume, which was determined by the ratio of the volume of a single spot to the whole set of spots. Only spots with significant (at least 1.5-fold quantitative changes) and reproducible changes in three replicates were used for mass spectrometry. Student's $t$-test and a significance level of $95 \%$ were used for the statistical analysis of the gels. Only the spots showing a statistically significant difference in protein abundance between the treatments were considered differentially expressed spots.

In-gel protein digestion, mass spectrometry and database search

Differentially expressed protein spots were excised from gels and transferred to sterilized $0.5 \mathrm{ml}$ tubes. The excised protein spots were destained for 20 min with $100 \mathrm{mM}$ $\mathrm{NH}_{4} \mathrm{HCO}_{3}$ in $30 \%$ acetonitrile (ACN) and then washed in Milli-Q $\mathrm{H}_{2} \mathrm{O}$. The spots were kept in $0.2 \mathrm{M} \mathrm{NH}_{4} \mathrm{HCO}_{3}$ for $20 \mathrm{~min}$ and then lyophilized and rehydrated. Each spot was digested overnight in $30 \mu \mathrm{l}$ of $50 \mathrm{mM} \mathrm{NH}_{4} \mathrm{HCO}_{3}$ containing $50 \mathrm{ng}$ trypsin (Promega, Madison, WI, USA). After overnight digestion at $37^{\circ} \mathrm{C}$, the peptides were extracted three times with a mixture of $50 \% \mathrm{ACN}$ and $0.1 \%$ $\mathrm{CF}_{3} \mathrm{CO}_{2} \mathrm{H}$ (TFA). Extracts were pooled together and lyophilized. The resulting lyophilized tryptic peptides were kept at $-80^{\circ} \mathrm{C}$ until mass spectrometric analysis.

\section{MALDI-TOF/TOF MS analysis and database searching}

MS and MS/MS spectra were obtained using the ABI 4800 Proteomics Analyzer MALDI-TOF/TOF (Applied Biosystems, Foster City, CA, USA) operating in a resultdependent acquisition mode. Peptide mass maps were acquired in positive ion reflector mode (20 kV accelerating voltage) with 1000 laser shots per spectrum. Monoisotopic peak masses were automatically determined within the mass range $800-4000 \mathrm{Da}$, with a signal to

Table 3 Primer sequences used in RT-PCR

\begin{tabular}{|c|c|c|c|}
\hline Transcripts & $\begin{array}{l}\text { Product } \\
\text { length } \\
(b p)\end{array}$ & $\begin{array}{l}\text { Annealing } \\
\text { temp. }\left({ }^{\circ} \mathrm{C}\right)\end{array}$ & Primer pairs \\
\hline \multirow[t]{2}{*}{ ahd } & 714 & 57 & S 5'-TCAAGGTCGCCAATCCCA-3' \\
\hline & & & AS 5'-TATGCCAGCAGCCTCAAAC-3' \\
\hline \multirow[t]{2}{*}{ vatps } & 427 & 57 & S 5'-GGCAGTGTTACTATTGTCGG-3' \\
\hline & & & AS 5'-TATTACGCATCATCCAGACC-3' \\
\hline \multirow[t]{2}{*}{$a d h$} & 415 & 57 & S 5’-AGGGTTCATCTGTTGCTATCT-3' \\
\hline & & & AS 5'-GGAATGTCAGTTCTCGGTI-3’ \\
\hline \multirow[t]{2}{*}{ ela } & 455 & 55 & S 5'-GTGGATTCGCTCCTAACA-3' \\
\hline & & & AS 5'-TTTCACAGCCTCAATACTCT-3' \\
\hline \multirow[t]{2}{*}{ SS } & 318 & 57 & S 5'-GAGTITGAGGTCCAGACTATTT-3' \\
\hline & & & AS 5'-AATTAACTGCTGCCTGAT-3' \\
\hline \multirow[t]{2}{*}{ gsk } & 663 & 53 & S 5'-TGCCAGTTGGACTTGACG-3' \\
\hline & & & AS 5'-GGGATGCTCGCTGATACA-3' \\
\hline \multirow[t]{2}{*}{ gs } & 427 & 55 & S 5'-CCAGGAGAAGACAGTGAA-3' \\
\hline & & & AS 5'-AGATGTAACGAGCAACCC-3' \\
\hline \multirow[t]{2}{*}{ pdh } & 437 & 55 & S 5'-CCCCAAATCTACCGTCTC-3' \\
\hline & & & AS 5'-AACTCCACAACAGGCTTC-3' \\
\hline \multirow[t]{2}{*}{$m d h$} & 294 & 53 & S 5'-TGAATGGCGTAAAGATGG-3' \\
\hline & & & AS 5'-GGATGGAAGGAGCAAACT-3 \\
\hline \multirow[t]{2}{*}{ pod } & 463 & 57 & S 5'-ATTCGCCTCCATTTCCAT-3' \\
\hline & & & AS 5'-GGCTTCCAGTTCCGTTGA-3' \\
\hline \multirow[t]{2}{*}{$\operatorname{atps} \beta$} & 459 & 57 & S 5'-TTGACCAGGCAACGGAACA-3' \\
\hline & & & $\begin{array}{l}\text { AS 5'-TACGACCAAGCAAAGCAGACAC- } \\
3^{\prime}\end{array}$ \\
\hline \multirow[t]{2}{*}{ ald } & 546 & 57 & S 5'-CTACAGAGGCAAATACGCT-3' \\
\hline & & & AS 5'-TCAGGCTCCACAATAGGT-3' \\
\hline \multirow[t]{2}{*}{ actin } & 290 & 58 & $\begin{array}{l}\text { S 5'-CCGTTCTGTCCCTCTACGCTAGTG- } \\
3^{\prime}\end{array}$ \\
\hline & & & $\begin{array}{l}\text { AS 5'- } \\
\text { GGAACTGCTCITTGCAGTCTCGAG-3 }\end{array}$ \\
\hline
\end{tabular}

S: Sense primer; AS: Anti-sense primer. 
noise ratio minimum set to 10 and a local noise window width of $m / z 250$. The most intense ions were selected as precursors for MS/MS acquisition, excluding common trypsin autolysis peaks and matrix ion signals. In MS/MS-positive ion mode, spectra were averaged, collision energy was $2 \mathrm{kV}$, and default calibration was set. Monoisotopic peak masses were automatically determined with a signal to noise ratio minimum set to 5 . The MS, together with MS/MS spectra were searched against the NCBI viridiplantae (V.2010.12.10, 184045 sequences) and NCBI EST viridiplantae databases (V.2010.12.10, 1847412 sequence) using the software GPS Explorer ${ }^{\mathrm{Tx}}$, version 3.6 (Applied Biosystems) and MASCOT version 2.1 (Matrix Science, London, UK). The parameters used for searching were: trypsin cleavage, one missed cleavage allowed; carbamidomethyl (C) set as a fixed modification; oxidation of methionines allowed as variable modification; peptide mass tolerance within $100 \mathrm{ppm}$; fragment tolerance set to $\pm 0.3 \mathrm{Da}$; and minimum ion score confidence interval for MS/MS data set to $95 \%$.

\section{RT-PCR analysis}

Total RNA was extracted from roots as described in the TRI reagent protocol (Takara Bio Inc). For all samples, total RNA $(1 \mu \mathrm{g})$ was converted to cDNA using a Superscript first-strand synthesis system for RT-PCR according to the manufacturer's instructions (Takara Bio Inc).

Primers were designed from the peptide sequences obtained after mass analysis according to NCBI and cucumber databases (cucumber.genomics.org.cn). Genespecific primers used for PCR are shown in Table 3. PCR conditions were optimized for each primer set. PCR was carried out by denaturing the cDNA at $94^{\circ} \mathrm{C}$ for $5 \mathrm{~min}$; followed by 30 cycles of $94^{\circ} \mathrm{C}$ for $30 \mathrm{~s}$, annealing temperature (shown in Table 3 ) for $30 \mathrm{~s}$, and extension at $72^{\circ} \mathrm{C}$ for $35 \mathrm{~s}$. The final PCR extension step was at $72^{\circ} \mathrm{C}$ for $7 \mathrm{~min}$. The amplified cDNA fragments were separated by $1 \%$ agarose gel electrophoresis.

\section{Western blot analysis}

The protein was extracted from roots using a mixture containing $0.5 \mathrm{M}$ Tris- $\mathrm{HCl}$ (pH 6.8), 20\% (v/v) glycerol, $2 \%$ $(\mathrm{w} / \mathrm{v})$ SDS, 5\% (v/v) $\beta$-mercaptoethanol and $0.01 \%(\mathrm{w} / \mathrm{v})$ bromophenol blue. The extracted protein was quantified by the Bradford method [88], denatured at $95^{\circ} \mathrm{C}$ for $3-5 \mathrm{~min}$ and then stored at $-20^{\circ} \mathrm{C}$ until analysis.

SDS-PAGE was performed according to the method of Laemmli [89]. After electrophoresis, protein bands were visualized with Coomassie blue R250. For western blot analysis, proteins (15 $\mu \mathrm{g}$ from each sample), separated by SDS-PAGE as above, were transferred to a $0.45 \mu \mathrm{m}$ PVDF membrane and detected with antibodies (produced in rabbit; Univ-bio, Shanghai, China) raised against $\mathrm{ADH}$
(AS10_685), PDC (AS10_691), and SAM (positive control). The membrane was blocked with $5 \%$ nonfat dry milk for $2 \mathrm{~h}$ and washed with TBST three times. The membrane was then probed with the appropriate rabbit primary antibody at a 1: 2000 dilution in TBST supplemented with $5 \%$ nonfat dry milk. After an overnight incubation at $4^{\circ} \mathrm{C}$, the membrane was washed with TBST and incubated at room temperature for $1 \mathrm{~h}$ with a Goat Anti-Rabbit IgG HRP-conjugate (1:1000 dilution with 5\% dry milk) in TBST. The membrane was then washed with TBST three times and developed using diamino benzidene (DAB) and $\mathrm{H}_{2} \mathrm{O}_{2}$.

\section{Additional file}

Additional file 1: Table S1. Effect of $\mathrm{Ca}^{2+}$ on biomass of cucumber seedlings under hypoxia stress [14]

Competing interests

The authors declare that they have no competing interests.

\section{Authors' contribution}

HLZ carried out the 2-DE experiments and mass spectrometry analysis. LXM carried out the western blot experiments. LB and YYJ participated in the RTPCR experiment. TJ and $\sqcup$ participated in sample collection and protein extraction. GSR conceived, designed, and coordinated this study. All authors read and approved the final manuscript.

\section{Acknowledgements}

The research was support by the National Basic Research Program of China (973 Program) (No.2009CB119000), the National Nature Science Foundation of China (No.30871736, 30900995, 31071831, and 30571263), and partially supported by the earmarked foundation for Modern Agro-industry Technology Research System (No.CARS-25-C-03).

\section{Author details}

'College of Horticulture, Nanjing Agriculture University/Key Laboratory of Southern Vegetable Crop Genetic Improvement, Ministry of Agriculture, Nanjing 210095, P. R. China. ${ }^{2}$ Anhui Science and Technology University, Fengyang, 233100, An Hui, P. R. China.

Received: 19 January 2012 Accepted: 20 June 2012

Published: 12 July 2012

References

1. Bailey-Serres J, Voesenek LACJ: Flooding stress: acclimations and genetic diversity. Annu Rev Plant Biol 2008, 59:313-339.

2. Sairam R, Kumutha D, Ezhilmathi K, Deshmukh P, Srivastava G: Physiology and biochemistry of waterlogging tolerance in plants. Biologia Plantarum 2008, 52:401-412.

3. Kang YY, Guo SR, Duan JJ: Effects of root zone hypoxia on respiratory metabolism of cucumber seedlings roots. Chin J Ecol 2008, 19:583-587.

4. Pedersen O, Rich SM, Colmer TD: Surviving floods: leaf gas films improve $\mathrm{O}_{2}$ and $\mathrm{CO}_{2}$ exchange, root aeration, and growth of completely submerged rice. Plant J 2009, 58:147-156.

5. Mommer L, Visser EJW: Underwater photosynthesis in flooded terrestrial plants: a matter of leaf plasticity. Ann Bot 2005, 96:581-589.

6. Kennedy RA, Rumpho ME, Fox TC: Anaerobic metabolism in plants. Plant Physiol 1992, 100:1

7. Li J, Sun J, Yang Y, Guo S, Glick BR: Identification of hypoxic-responsive proteins in cucumber roots using a proteomic approach. Plant Physiol Biochem 2012, 51:74-80.

8. Henriksson E, Nordin Henriksson K: Salt-stress signalling and the role of calcium in the regulation of the Arabidopsis ATHB7 gene. Plant Cell Environ 2005, 28:202-210. 
9. Aurisano N, Bertani A, Reggiani R: Involvement of calcium and calmodulin in protein and amino acid metabolism in rice roots under anoxia. Plant Cell Physiol 1995, 36:1525-1529.

10. Gao H, Chen G, Han L, Lin H: Calcium influence on chilling resistance of grafting eggplant seedlings. J Plant Nutr 2005, 27:1327-1339.

11. Yemelyanov V, Shishova M, Chirkova T, Lindberg S: Anoxia-induced elevation of cytosolic $\mathrm{Ca}^{2+}$ concentration depends on different $\mathrm{Ca}^{2+}$ sources in rice and wheat protoplasts. Planta 2011, 234:271-280

12. Subbaiah CC, Bush DS, Sachs MM: Mitochondrial contribution to the Anoxic $\mathrm{Ca}^{2+}$ signal in maize suspension-cultured cells. Plant Physiol 1998 118:759-771.

13. Gao H, Guo S: Influence of calcium on antioxidant system and nitrogen metabolism of muskmelon seedlings under nutrient solution hypoxia. Acta Hort. (ISHS) 2004, 691:321-328.

14. He LZ, Guo SR, Lu XM, Wang LP, Yang YJ: Effects of calcium on soluble protein expression of cucumber seedlings under roo-zoon hypoxia stress. J Nanjing Agric Univ 2012, 35:21-25.

15. Evans NH, McAinsh MR, Hetherington AM, Knight MR: ROS perception in Arabidopsis thaliana: the ozone-induced calcium response. Plant J 2005 41:615-626

16. Walz C, Giavalisco P, Schad M, Juenger M, Klose J, Kehr J: Proteomics of curcurbit phloem exudate reveals a network of defence proteins. Phytochemistry 2004, 65:1795-1804.

17. Buhtz A, Kolasa A, Arlt K, Walz C, Kehr J: Xylem sap protein composition is conserved among different plant species. Planta 2004, 219:610-618.

18. Segarra G, Casanova E, Bellido D, Odena MA, Oliveira E, Trillas I: Proteome, salicylic acid, and jasmonic acid changes in cucumber plants inoculated with Trichoderma asperellum strain T34. Proteomics 2007, 7:3943-3952.

19. Donnini S, Prinsi B, Negri A, Vigani G, Espen L, Zocchi G: Proteomic characterization of iron deficiency responses in Cucumis sativus L. roots. BMC Plant Biol 2010, 10:268

20. Du CX, Fan HF, Guo SR, Tezuka T, Li J: Proteomic analysis of cucumber seedling roots subjected to salt stress. Phytochemistry 2010, 71:1450-1459.

21. Todaka D, Kanekatsu M: Analytical method for detection of beta-amylase isozymes in dehydrated cucumber cotyledons by using two-dimensional polyacrylamide gel electrophoresis. Anal Biochem 2007, 365:277.

22. Juszczuk IM, Rychter AM: BN-PAGE analysis of the respiratory chain complexes in mitochondria of cucumber MSC16 mutant. Plant Physiol Biochem 2009, 47:397-406

23. Li Q, Huang J, Liu S, Li J, Yang X, Liu Y, Liu Z: Proteomic analysis of young leaves at three developmental stages in an albino tea cultivar. Proteome Sci 2011, 9:44.

24. Bevan M, Bancroft I, Bent E, Love K, Goodman H, Dean C, Bergkamp R, Dirkse W, Van Staveren M, Stiekema W: Analysis of $1.9 \mathrm{Mb}$ of contiguous sequence from chromosome 4 of Arabidopsis thaliana. Nature 1998 391:485.

25. Denton RM, Randle PJ, Bridges BJ, Cooper RH, Kerbey AL, Pask HT, Severson $\mathrm{DL}$, Stansbie D, Whitehouse S: Regulation of mammalian pyruvate dehydrogenase. Mol Cell Biochem 1975, 9:27-53.

26. Beinert $H$, Kennedy M: Aconitase, a two-faced protein: enzyme and iron regulatory factor. FASEB J 1993, 7:1442-1449.

27. Flint $\mathrm{DH}$, Allen RM: Iron - sulfur proteins with nonredox functions. Chem Rev 1996, 96:2315-2334.

28. Yao YX, Li M, Zhai H, You CX, Hao YJ: Isolation and characterization of an apple cytosolic malate dehydrogenase gene reveal its function in malate synthesis. J Plant Physiol 2011, 168:474-480.

29. Tesfaye M, Temple SJ, Allan DL, Vance CP, Samac DA: Overexpression of Malate Dehydrogenase in Transgenic Alfalfa enhances organic acid synthesis and confers tolerance to aluminum. Plant Physiol 2001, 127:1836-1844.

30. Yao YX, Dong QL, Zhai H, You CX, Hao YJ: The functions of an apple cytosolic malate dehydrogenase gene in growth and tolerance to cold and salt stresses. Plant Physiol Biochem 2011, 49:257-264

31. $\mathrm{Hu} X \mathrm{H}, \mathrm{Li}$ J, GuO SR, Li Ji: Effects of $\mathrm{Ca}^{2+}$ on respiratory metabolism in roots of cucumber seedlings under root-zone hypoxia stress. Acta Hortic $\sin 2007,33: 1113-1116$.

32. Zhang ER, Ren YY, Hu HQ, Liu YH, Chen SS: Effects of calcium on growth and respiratory metabolism of hot pepper seedling roots under flood stress. Acta Hortic Sin 2009, 36:1749-1754.

33. Yan S, Tang Z, Su W, Sun W: Proteomic analysis of salt stress-responsive proteins in rice root. Proteomics 2005, 5:235-244.
34. Lee DG, Ahsan N, Lee SH, Lee JJ, Bahk JD, Kang KY, Lee BH: Chilling stressinduced proteomic changes in rice roots. J Plant Physio/ 2009, 166:1-11.

35. Zhao J, Zuo K, Tang K: cDNA Cloning and Characterization of Enolase from Chinese Cabbage, Brassica campestris ssp. Pekinensis. Mitochondrial DNA 2004, 15:51-57.

36. Riccardi F, Gazeau P, de Vienne D, Zivy M: Protein changes in response to progressive water deficit in maize. Plant Physiol 1998, 117:1253-1263.

37. Forsthoefel NR, Cushman M, Cushman JC: Posttranscriptional and Posttranslational Control of Enolase Expression in the Facultative Crassulacean Acid Metabolism Plant Mesembryanthemum crystallinum L. Plant Physiol 1995, 108:1185-1195.

38. Jedrzejas MJ: Structure, function, and evolution of phosphoglycerate mutases: comparison with fructose-2,6-bisphosphatase, acid phosphatase, and alkaline phosphatase. Prog Biophys Mol Biol 2000, 73:263-287

39. Zhao Z, Assmann SM: The glycolytic enzyme, phosphoglycerate mutase, has critical roles in stomatal movement, vegetative growth, and pollen production in Arabidopsis thaliana. J Exp Bot 2011, 62:5179-5189.

40. Westram A, Lloyd JR, Roessner U, Riesmeier JW, Kossmann J: Increases of 3phosphoglyceric acid in potato plants through antisense reduction of cytoplasmic phosphoglycerate mutase impairs photosynthesis and growth, but does not increase starch contents. Plant Cell Environ 2002, 25:1133-1143.

41. Matsumoto M, Ogawa Ki: New insight into the Calvin Cycle Regulation Glutathionylation of Fructose Bisphosphate Aldolase in Response to Illumination. In Photosynthesis Energy from the Sun. Edited by Allen JF, Gantt E, Golbeck JH, Osmond B. Netherlands: Springer; 2008:872-874.

42. Konishi $\mathrm{H}$, Kitano $\mathrm{H}$, Komatsu S: Identification of rice root proteins regulated by gibberellin using proteome analysis. Plant Cell Environ 2005, 28:328-339.

43. Schaeffer GW, Sharpe FT, Sicher RC: Fructose 1,6-bisphosphate aldolase activity in leaves of a rice mutant selected for enhanced lysine. Phytochemistry 1997, 46:1335-1338.

44. Rocha M, Licausi F, Araujo WL, Nunes-Nesi A, Sodek L, Fernie AR, van Dongen JT: Glycolysis and the Tricarboxylic Acid Cycle are linked by Alanine Aminotransferase during Hypoxia Induced by Waterlogging of Lotus japonicus. Plant Physiol 2010, 152:1501-1513.

45. Johnson JR, Cobb BG, Drew MC: Hypoxic Induction of Anoxia Tolerance in Roots of Adh1 Null Zea mays L. Plant Physiol 1994, 105:61-67.

46. Subbaiah CC, Zhang J, Sachs MM: Involvement of Intracellular Calcium in Anaerobic Gene Expression and Survival of Maize Seedlings. Plant Physiol 1994, 105:369-376.

47. Nie X, Durnin D, Igamberdiev A, Hill R: Cytosolic calcium is involved in the regulation of barley hemoglobin gene expression. Planta 2006, 223: 542-549.

48. Szydlowski N, Ragel P, Raynaud S, Lucas MM, Roldán I, Montero M, Muñoz FJ, Ovecka M, Bahaji A, Planchot V, et al: Starch Granule Initiation in Arabidopsis Requires the Presence of Either Class IV or Class III Starch Synthases. The Plant Cell Online 2009, 21:2443-2457.

49. Zhang X, Szydlowski N, Delvallé D, D'Hulst C, James M, Myers A: Overlapping functions of the starch synthases SSII and SSIII in amylopectin biosynthesis in Arabidopsis. BMC Plant Biol 2008, 8:96

50. Miao M, Xu X, Chen X, Xue L, Cao B: Cucumber carbohydrate metabolism and translocation under chilling night temperature. J Plant Physiol 2007, 164:621-628.

51. Rosa M, Prado C, Podazza G, Interdonato R, González JA, Hilal M, Prado FE: Soluble sugars-Metabolism, sensing and abiotic stress: A complex network in the life of plants. Plant Signal Behav 2009, 4:388.

52. Eveland AL, Jackson DP: Sugars, signalling, and plant development. J Exp Bot 2011, 63(9):3367-3377.

53. Van Dongen JT, Roeb GW, Dautzenberg M, Froehlich A, Vigeolas $H$, Minchin PEH, Geigenberger P: Phloem Import and Storage Metabolism Are Highly Coordinated by the Low Oxygen Concentrations within Developing Wheat Seeds. Plant Physiol 2004, 135:1809-1821.

54. Gupta KJ, Zabalza A, Van Dongen JT: Regulation of respiration when the oxygen availability changes. Physiol Plant 2009, 137:383-391.

55. Geigenberger P: Response of plant metabolism to too little oxygen. Curr Opin Plant Biol 2003, 6:247-256.

56. Miflin BJ, Habash DZ: The role of glutamine synthetase and glutamate dehydrogenase in nitrogen assimilation and possibilities for 
improvement in the nitrogen utilization of crops. J Exp Bot 2002, 53:979-987.

57. Habash DZ, Massiah AJ, Rong HL, Wallsgrove RM, Leigh RA: The role of cytosolic glutamine synthetase in wheat. Ann Appl Biol 2001, 138:83-89.

58. Vincent R, Fraisier V, Chaillou S, Limami MA, Deleens E, Phillipson B, Douat C, Boutin JP, Hirel B: Overexpression of a soybean gene encoding cytosolic glutamine synthetase in shoots of transgenic Lotus corniculatus L. plants triggers changes in ammonium assimilation and plant development. Planta 1997, 201:424-433.

59. Cross RL, Müller V: The evolution of A-, F-, and V-type ATP synthases and ATPases: reversals in function and changes in the H+/ATP coupling ratio. FEBS Lett 2004, 576:1-4.

60. Rappas M, Niwa H, Zhang X: Mechanisms of ATPases-A multi-disciplinary approach. Curr Protein Pept Sci 2004, 5:89-105.

61. Chinnusamy V, Jagendorf A, Zhu JK: Understanding and improving salt tolerance in plants. Crop Sci 2005, 45:437-448

62. Jouaville LS, Pinton P, Bastianutto C, Rutter GA, Rizzuto R: Regulation of mitochondrial ATP synthesis by calcium: evidence for a long-term metabolic priming. Proc Natl Acad Sci 1999, 96:13807-13812.

63. Chung HJ, Ferl RJ: Arabidopsis alcohol dehydrogenase expression in both shoots and roots is conditioned by root growth environment. Plant Physiol 1999, 121:429-436.

64. Rhoads DM: Plant mitochondrial retrograde regulation. In Plant Mitochondria. Volume 1. Edited by Kempken F. New York: Springer; 2011:411-437. Advances in Plant Biology.

65. Gao H, Jia Y, Guo S, Lv G, Wang T, Juan L: Exogenous calcium affects nitrogen metabolism in root-zone hypoxia-stressed muskmelon roots and enhances short-term hypoxia tolerance. J Plant Physiol 2011 168:1217-1225.

66. Peter G: Response of plant metabolism to too little oxygen. Curr Opin Plant Biol 2003, 6:247-256.

67. Drew MC, He CJ, Morgan PW: Programmed cell death and aerenchyma formation in roots. Trends Plant Sci 2000, 5:123-127.

68. Smalle J, Kurepa J, Yang P, Babiychuk E, Kushnir S, Durski A, Vierstra RD: Cytokinin growth responses in Arabidopsis involve the 26S Proteasome subunit RPN12. The Plant Cell Online 2002, 14:17-32.

69. Vlad F, Rubio S, Rodrigues A, Sirichandra C, Belin C, Robert N, Leung J, Rodriguez $\mathrm{PL}$, Laurière $\mathrm{C}$, Merlot $\mathrm{S}$ : Protein phosphatases $2 \mathrm{C}$ regulate the activation of the Snf1-related kinase OST1 by Abscisic acid in Arabidopsis. The Plant Cell Online 2009, 21:3170-3184.

70. Lammers T, Lavi S: Role of Type 2C Protein Phosphatases in Growth Regulation and in Cellular Stress Signaling. Crit Rev Biochem Mol Biol 2007, 42:437-461

71. Havrylenko S, Legouis R, Negrutskii B, Mirande M: Methionyl-tRNA synthetase from Caenorhabditis elegans: A specific multidomain organization for convergent functional evolution. Protein Sci 2010, 19:2475-2484.

72. Menand B, Maréchal-Drouard L, Sakamoto W, Dietrich A, Wintz H: A single gene of chloroplast origin codes for mitochondrial and chloroplastic methionyl-tRNA synthetase in Arabidopsis thaliana. Proc Natl Acad SCi 1998, 95:11014-11019.

73. Millar H, Considine MJ, Day DA, Whelan J: Unraveling the Role of Mitochondria During Oxidative Stress in Plants. IUBMB Life 2001, 51:201-205.

74. Sairam RK, Dharmar K, Lekshmy S, Chinnusamy V: Expression of antioxidant defense genes in mung bean (Vigna radiata L.) roots under waterlogging is associated with hypoxia tolerance. Acta Physiol Plant 2010, 33:735-744

75. Parida AK, Das AB: Salt tolerance and salinity effects on plants: a review. Ecotoxicol Environ Saf 2005, 60:324-349.

76. Saraiva JA, Nunes CS, Coimbra MA: Purification and characterization of olive (Olea europaea L.) peroxidase - evidence for the occurrence of a pectin binding peroxidase. Food Chem 2007, 101:1571-1579.

77. Ikehata K, Buchanan ID, Pickard MA, Smith DW: Purification, characterization and evaluation of extracellular peroxidase from two Coprinus species for aqueous phenol treatment. Bioresour Technol 2005, 96:1758-1770.

78. Sairam R, Kumutha D, Ezhilmathi K, Chinnusamy V, Meena R: Waterlogging induced oxidative stress and antioxidant enzyme activities in pigeon pea. Biol Plant 2009, 53:493-504.
79. Kang Yy, Guo Sr, Li J, Duan Jj: Effects of 24-Epibrassinolide on antioxidant system in cucumber seedling roots under hypoxia stress. Agric Sci China 2007, 6:281-289

80. Wang CY, Guo SR, Liu CJ: Effects of calcium on expression of defense enzymes isoenzymes in roots of cucumber seedlings under root-zone hypoxic stress. Acta Bot Boreali-Occidentalia Sin 2009, 9:1874-1880.

81. Mustroph A, Boamfa E, Laarhoven L, Harren F, Albrecht G, Grimm B: Organspecific analysis of the anaerobic primary metabolism in rice and wheat seedlings. I: dark ethanol production is dominated by the shoots. Planta 2006, 225:103-114.

82. Kang YY, Guo SR, Li J, Duan JJ: Effect of root applied 24-epibrassinolide on carbohydrate status and fermentative enzyme activities in cucumber (Cucumis sativus L.) seedlings under hypoxia. Plant Growth Regul 2009, 57:259-269.

83. Yan SP, Zhang QY, Tang ZC, Su WA, Sun WN: Comparative Proteomic Analysis Provides New Insights into Chilling Stress Responses in Rice. Mol Cell Proteomics 2006, 5:484-496.

84. Ma YH, Guo SR: On different hypoxia tolerance of thirteen cucumber varieties. Jiangsu Agric Sci 2004, 5:68-70.

85. Hurkman WJ, Tanaka CK: Solubilization of plant membrane proteins for analysis by two-dimensional gel electrophoresis. Plant Physiol 1986, 81:802.

86. Duncan R, Hershey JWB: Evaluation of isoelectric focusing running conditions during two-dimensional isoelectric focusing/sodium dodecyl sulfate-polyacrylamide gel electrophoresis: variation of gel patterns with changing conditions and optimized isoelectric focusing conditions. Anal Biochem 1984, 138:144-155.

87. O'Farrell PH: High resolution two-dimensional electrophoresis of proteins. J Biol Chem 1975, 250:4007.

88. Bradford MM: A rapid and sensitive method for the quantitation of microgram quantities of protein utilizing the principle of protein-dye binding. Anal Biochem 1976, 72:248-254.

89. Laemmli UK: Cleavage of structural proteins during the assembly of the head of bacteriophage T4. Nature 1970, 227:680-685.

doi:10.1186/1477-5956-10-42

Cite this article as: He et al:: Proteomic analysis of the effects of exogenous calcium on hypoxic-responsive proteins in cucumber roots. Proteome Science 2012 10:42.

\section{Submit your next manuscript to BioMed Central and take full advantage of:}

- Convenient online submission

- Thorough peer review

- No space constraints or color figure charges

- Immediate publication on acceptance

- Inclusion in PubMed, CAS, Scopus and Google Scholar

- Research which is freely available for redistribution 